DOI: https://doi.org/10.31933/dijemss.v2i3

Received: $21^{\text {st }}$ November 2020, Revised: $15^{\text {th }}$ January 2021, Publish: $3^{\text {nd }}$ March 2021

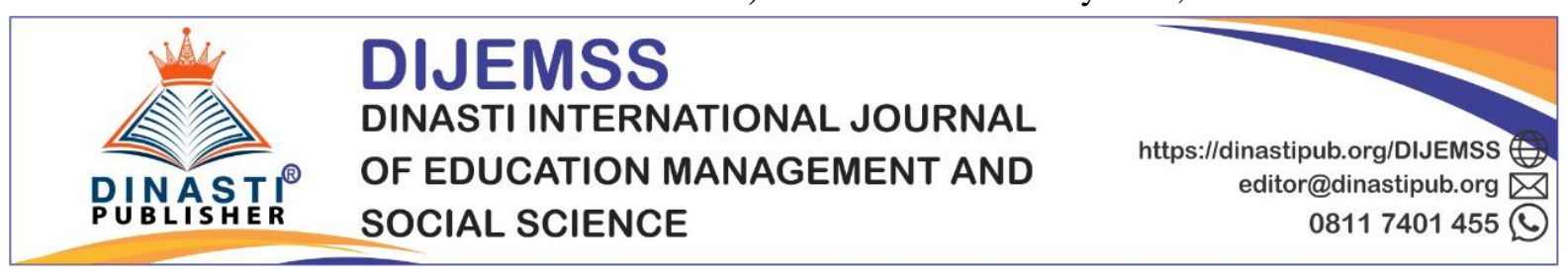

\title{
ANALYSIS OF THE EFFECT OF DISCIPLINE, JOB SATISFACTION, AND WORK MOTIVATION, TO EMPLOYEE PERFORMANCE AT PT. POS INDONESIA, CENTRAL JAKARTA BRANCH
}

\author{
Muhammad Abdul Muis ${ }^{1}$, Amrison Amrison ${ }^{2}$ \\ ${ }^{1)}$ Politeknik Bisnis dan Pasar Modal, Indonesia, Muis.pknstan@ gmail.com \\ ${ }^{2)}$ Universitas Persada Indonesia Y.A.I, Indonesia, Amrisonatb@gmail.com
}

Corresponding Author: Muhammad Abdul Muis ${ }^{1}$

Abstract: This study aimed to analyze the effect of discipline, job satisfaction, and work motivation on employee performance at PT. Pos Indonesia, Central Jakarta Branch

The research methodology used a quantitative method with cross-section data and primary data obtained from questionnaires. Mechanical sampling using a purposive sampling method with the data in 2019. The data analysis technique used is multiple linear regression to test the validity, reliability test, the test model stability, linearity test, normality test, classic assumption test (multicollinearity test, heteroscedasticity test) and hypothesis testing $t$ statistic and f-statistic to examine the effects together with a significance level of 5\%.

The results of this study showed that in partial variable Motivation of work, Discipline, and Job Satisfaction has a positive and significant impact on the Satisfaction of Employee Performance. Meanwhile, the independent variable of Motivation of work, Discipline, and Job Satisfaction with together have a significant relationship to the dependent variable, Satisfaction of Employee Performance. Coefficient of determination from this study showed 72.03\% result, it shows that the variation of the independent variables are Motivation of work, Discipline and Job Satisfaction can explain the rise and fall of the dependent variable variation Satisfaction of Employee Performance is $72.03 \%$, while the remaining $27.97 \%$ affected by other independent variables.

Keywords: work motivation, Discipline, Job Satisfaction, Employee Performance.

\section{INTRODUCTION}

The rapid development of the economy and technology in the globalization era has brought about significant changes in human life. This change is shown in business competition in shipping services with companies that make shipping services the main market share in a company that is run. With so many diverse competitors, companies must work hard in managing market share properly to create effective and efficient company goals. 
One of the factors for the creation of effective and efficient company goals is human resources. In achieving work productivity, human resources have an important function for the company. Because it is human resources that can determine the high and low welfare that will be obtained at the company. In the era of rapid globalization, not only humans are the most important for a company, but performance is also an important thing for a company.

Employee performance is the ability or effort achieved by an employee in carrying out a job description by the responsibilities that have been given. To find out the factors that affect the performance of Schermerhon et.al, (1982 cit. Rahadi, 2010, p. 6) reveal the various performance management variables that will have an impact on organizational management.

Table 1, Employee Performance Variables

\begin{tabular}{|l|l|l|}
\hline Variables & Key Factor & Managerial Implications \\
\hline Individual attributes & $\begin{array}{l}\text { Demographic, competency, and } \\
\text { psychological characteristics }\end{array}$ & $\begin{array}{l}\text { To do a good job recruiting, } \\
\text { selecting, and training employees }\end{array}$ \\
\hline Work effort & $\begin{array}{l}\text { To do a good job of allocating } \\
\text { work-related rewards }\end{array}$ \\
\hline Organizational support & $\begin{array}{l}\text { Work group dynamics, organization, } \\
\text { size, structure, and technology, } \\
\text { resources, goals, leadership }\end{array}$ & $\begin{array}{l}\text { To do a good job planning, } \\
\text { organizing, directing, and } \\
\text { controlling workflows and the } \\
\text { worksetting }\end{array}$ \\
\hline
\end{tabular}

Source: Schermerhon et.al, (1982 cit. Rahadi, 2010, p. 6)

Therefore, a company's success can be seen in employee performance. Because if a company has good employee performance in terms of quantity and quality, likely, the company will quickly reach the target market share that has been targeted. Employee performance in the company is also supported by regular and good company management. Usually, a company manages orderly and well through a POAC (Planning Organizing, Actuating, and Controlling )

Management is a process for an activity that regulates and directs a group of people or employees to achieve a company goal effectively and efficiently. Good and orderly management can make employees feel comfortable working and the company will quickly achieve its goals. Because the success or failure of the company can usually be seen if every year the company is successful in the target market share.

PT. Pos Indonesia is an Indonesian state-owned company engaged in shipping services and financial services. At first PT. Pos Indonesia was established in Jakarta on August 26, 1976 by Governor General GW Baron Van Imhoff who only served letters and postal packages on the island of Java and outside Java. Over time, PT. Pos Indonesia is getting better and more successful in market share in terms of serving letters and packages. Entering 2000 to 2008 PT. Pos Indonesia began to experience a drastic decline and has been losing annually 606.5 billion. However, after the enactment of Law NO. 38 of 2009 concerning the post of business transformation, now PT. Pos Indonesia has formed 6 (six) subsidiaries, revitalized its core business, and developed new businesses. Even now PT. Pos Indonesia has begun to enter into the retail, property and insurance business. In 2013 PT. Pos Indonesia also provides office management and rental services and MICE rooms (meetings, incentives, conventions, exhibitions)

As one of the companies engaged in shipping services, PT. Pos Indonesia has a mission "to make a profit" is required to provide the best possible service to customers because in the principle of dealing with other people and also fulfilling their needs the key is in "providing services". One of the competitiveness in the company is how the company 
carries out excellent and good service by improving existing performance. However, in practice, many often ignore the meaning of service to customers, even though if this can be done well it will be seen whether a company is successful or not in targeting market share in serving the needs of others.

If seen from the mission of PT Pos Indonesia, which wants its employees to be able to carry out this mission well, the company should also be able to give its employees the desire to feel comfortable with their work and love their work. Because not long ago, on February 6, 2019, the news about PT. Pos Indonesia is currently being discussed. Thousands of employees of PT. Pos Indonesia has acted to block the highway of the southern independent field or in front of the Ministry of State-Owned Enterprises (BUMN). The action was carried out because the demonstrators asked to change the board of directors of PT. Indonesian post. This was done because the demonstrators thought that the board of directors was no longer able to manage the company properly. The anxiety caused by these employees originated from late payment of employee salaries, reduction of employee rights, and unpaid overtime costs. Whereas a company if there are no human resources or employees, it will not be able to run well. (metrotvnews).

Employees are a valuable resource in the company. Therefore, the selection of employees in a company is very important to be done carefully and well because it can affect work motivation, discipline, job satisfaction, and employee performance which have an impact on the success or failure of the company. The long stage that a company takes in selecting employees is not just a formality. Usually, a company already has its criteria for finding new employees at the company. It is not only human resources and employee performance that are important in the company. Good behavior, environment, and management are also of the utmost importance.

In the scope of the company if a manager only pays attention to one part, then the part that doesn't get attention will feel unappreciated. This can result in ineffective work. Because behavior is one part of the whole process and work results. A comfortable environment is also an important thing, if employees feel comfortable working in a company, the employee will carry out their duties optimally and very well. Therefore, if the manager wants to pay attention so that employees feel motivated, disciplined, and feel job satisfaction must be done to all employees, not just one part.

So from the description above, it can be concluded that work motivation, discipline, and job satisfaction can affect employee performance. By studying and analyzing how the character of employees in employee performance is an important thing to do because, with good basic knowledge about it, it will be able to provide meaningful input for employee performance management planning. Because in essence work motivation, discipline, and job satisfaction can have an impact on the success or failure of a company.

The formulation of the problem in this study is as follows:

1. How Does Discipline Have Effect On Employee Performance?

2. How Does Job Satisfaction Have Effect On Employee Performance?

3. How Does Work Motivation Have Effect On Employee Performance?

4. How simultaneous Effect Of Discipline,Job Satisfaction, and Work Motivation, On Employee Performance? 


\section{LITERATURE REVIEW \\ Definition of Management}

According to the book Hasibuan (2018, pp. 1-2) management comes from the word to manage which means to manage. Arrangements are made through processes and arranged according to the order of the management functions. So, management is a process to achieve the desired goals. As for the book Terry (2006, p. 9) Management is "an activity, its implementation is called managing and the person who does it is called a manager. As a manager, he is handling new tasks which are entirely "managerial" which is important including stopping the tendency to do things by himself.

\section{Definition of Human Resource Management}

Human resource management is a strategic area of the organization. Human resource management should be seen as an extension of the traditional view of managing people effectively and for that it requires knowledge of human behavior and the ability to manage it.

There are various opinions regarding the notion of human resource management, including those who create human resources, some interpret it as manpower management and some that equate the notion of human resources with personnel (personnel, staffing, and so on). However, in human resource management that may be appropriate is human resources management, thus simply the definition of Human Resource Management is Managing Human Resources. (Sutrisno 2017, p. 5).

\section{Definition of Work Motivation}

According to Arifin and Muhammad (2016, pp. 101-102) The term motivation comes from the Latin word Molvere which means to move (to move), namely the psychological process which is the goal and direction of each behavior. Motivation is a condition in a person's personality that encourages individual desire to carry out certain activities in order to achieve a goal. The motivation that is in someone will manifest a behavior that is directed at the goal of achieving goals. According to Feriyanto and Triana (2015, p. 71) motivation is a suggestion or encouragement that arises because it is given by someone to another person or from oneself, it can also be interpreted as a reason that underlies an action done by someone who explains the intensity, direction and perseverance of an individual to achieve his goals.

Based on this understanding, it can be said that Work Motivation is an impulse or situation in a person that arises because someone encourages an individual's desire to carry out certain activities, or it can also be an excuse that is intended to be better than the previous one.

\section{Definition Discipline}

According to Rivai and Sagala 2009, pp. 823-825) explains that work discipline is a tool used by managers to communicate with employees so that they are willing to change a behavior and as an effort to increase one's awareness and willingness to obey all company regulations and applicable social norms. 


\section{Definition of Job Satisfaction}

According to Priansa (2017, p. 255) Job Satisfaction is a set of employee feelings about their work, such as happy or unhappy, like or dislike as a result of employee interaction with their work environment or the results of employee assessments of their work.

\section{Definition Employee performance}

According to Priansa (2017, p. 48) Performance (work performance) is a manifestation of ability in the form of real work or work achieved by employees in tasks and jobs originating from the company.

\section{CONCEPTUAL FRAMEWORK}

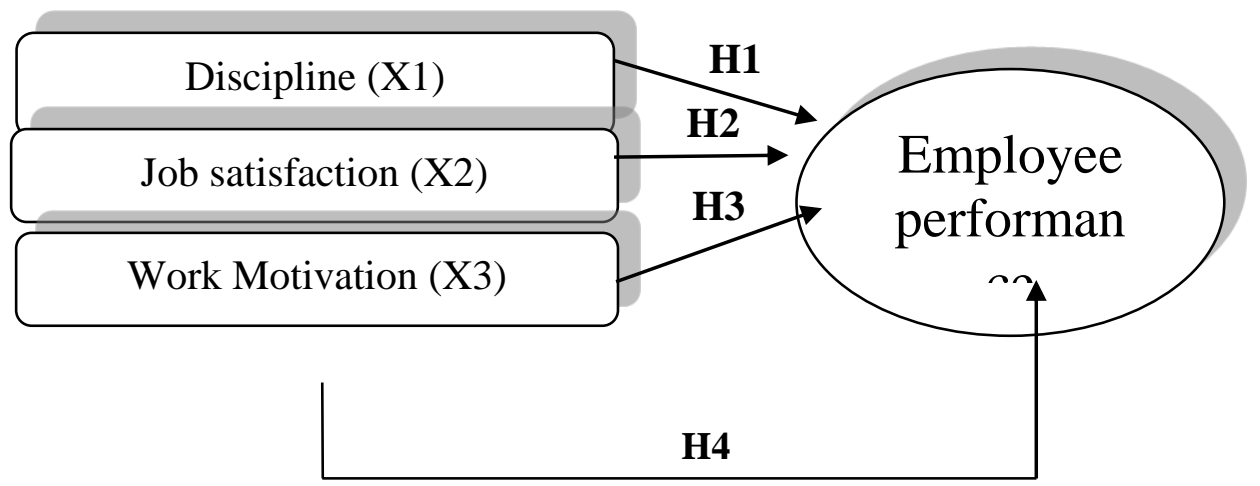

Source: Data processed by the author, 2019

\section{RESEARCH METHODS}

in this study, the type of research This is descriptive quantitative research with a case study approach, namely the company PT. Pos Indonesia, Central Jakarta branch in 2019 by distributing questionnaires distributed to employees of PT. Pos Indonesia,Central Jakarta Branch.

The population which is the object of this research is Company employees who work at PT. Pos Indonesia,Central Jakarta Branch.

Determination of the sample used in this study using a sample (sample size), namely by using various statistical formulas, so that the samples were taken from the population meet the requirements of an acceptable level of confidence and a possible tolerable level of sample error.

To analyze the influence between independent variables on the dependent variable through the multiple linear regression analysis method approach. This analysis can be used to obtain a comprehensive picture of the relationship between the dependent and independent variables as a whole, either simultaneously or partially. This analysis tool in this study is translated into the variables used for multiple regression analysis as follows: 


\section{Work motivation}

Table 2, Variables, Definitions, and Indicators of Work Motivation

\begin{tabular}{|c|c|c|}
\hline Variable & Definition & Indicator \\
\hline $\begin{array}{l}\text { Work } \\
\text { motivation }\end{array}$ & $\begin{array}{l}\text { A reason or impulse that directs, } \\
\text { awakens and underlies a person in } \\
\text { doing work or other things. }\end{array}$ & $\begin{array}{l}\text { 1. Skills } \\
\text { 2. Corporate responsibility } \\
\text { 3. Award for work } \\
\text { performance } \\
\text { 4. Level of need for self- } \\
\text { actualization } \\
\text { 5. Level of Concern among } \\
\text { workers }\end{array}$ \\
\hline
\end{tabular}

Source: Data processed by the author, 2019

\section{Work Discipline}

Table 3, Variables, Definitions, and Indicators of Work Discipline

\begin{tabular}{|l|l|l|}
\hline \multicolumn{1}{|c|}{ Variable } & \multicolumn{1}{|c|}{ Definition } & \multicolumn{1}{c|}{ Indicator } \\
\hline \multirow{2}{*}{$\begin{array}{l}\text { Work } \\
\text { Discipline }\end{array}$} & $\begin{array}{l}\text { Attitudes and behavior of a person to } \\
\text { comply with and obey all guidelines } \\
\text { or regulations that have been made } \\
\text { by the company in order to achieve } \\
\text { company goals effectively and } \\
\text { efficiently. }\end{array}$ & $\begin{array}{l}\text { 1. Punctuality of work } \\
\text { 2. Compliance with } \\
\text { regulations }\end{array}$ \\
& $\begin{array}{l}\text { 3. Complete work facilities } \\
\text { and infrastructure }\end{array}$ \\
& $\begin{array}{l}\text { 4. Willingness to work } \\
\text { without supervision } \\
\text { Carry out duties and } \\
\text { obligations }\end{array}$ \\
\hline
\end{tabular}

Source: Data processed by the author, 2019

\section{Job satisfaction}

Table 4 Variables, Definitions, and Job Satisfaction Indicators

\begin{tabular}{|c|c|c|}
\hline Variable & Definition & Indicator \\
\hline $\begin{array}{l}\text { Job } \\
\text { satisfaction }\end{array}$ & $\begin{array}{l}\text { The attitude of a person in showing a } \\
\text { job with pleasure or displeasure, like } \\
\text { or dislike of it. }\end{array}$ & $\begin{array}{l}\text { 1. The completeness and } \\
\text { comfort of the work } \\
\text { environment } \\
\text { 2. Promotion increase rate } \\
\text { 3. Co-workers } \\
\text { 4. Superior trust level } \\
\text { 5. Salary suitability level }\end{array}$ \\
\hline
\end{tabular}

Source: Data processed by the author, 2019

\section{Employee performance}

Table 5 Variables, Definitions, and Employee Performance Indicators

\begin{tabular}{|c|c|c|}
\hline Variable & Definition & Indicator \\
\hline
\end{tabular}




\begin{tabular}{|c|c|c|}
\hline $\begin{array}{l}\text { Employee } \\
\text { performance }\end{array}$ & $\begin{array}{l}\text { Performance is a general term used } \\
\text { for part or all of the actions on the } \\
\text { activities of an organization. }\end{array}$ & $\begin{array}{l}\text { 1. Quantity of work } \\
\text { 2. Quality of work } \\
\text { 3. Willingness to work } \\
\text { without supervision } \\
\text { 4. The level of working } \\
\text { relationships with } \\
\text { colleagues } \\
\text { 5. Work effectiveness } \\
\text { 6. Work commitment } \\
\text { 7. The level of initiative at } \\
\text { work } \\
\text { 8. The conformity of work } \\
\text { results with established } \\
\text { standards } \\
\text { 9. Safety at work }\end{array}$ \\
\hline
\end{tabular}

Source: Data processed by the author, 2019

\section{FINDINGS AND DISCUSSION}

The results of the validity test using the help of the Eviews 7.0 program, shows that the results of the validity test provide a very good value that the calculated r-value of all indicators of work motivation, discipline, job satisfaction, and employee performance is greater than the $r$ table. $r$ count contained is the average of the number of $r$ counts obtained from each question that has been asked for employees of PT. Pos Indonesia,Central Jakarta Branch. It can be seen that the $r$ count is higher than $r$ table $0.1654(\mathrm{n}=98)$. Therefore it can be concluded that all indicators of work motivation, discipline, job satisfaction, and employee performance in this study are valid.

Based on the data above, it shows that the reliability test results using the Eviews 7.0 program are categorized as very reliable. where the result of $r$ count 0.9365 is greater than Cronbach's alpha. As a rule, if the $r$ count is greater than Cronbach's alpha, it can be said to be very reliable..

Figure 1, Normality test

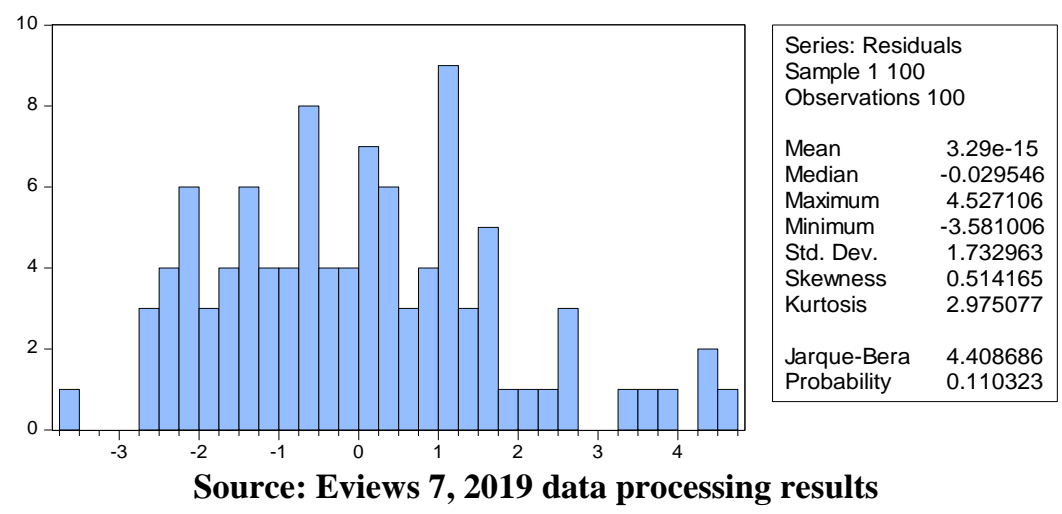

Based on these results it appears that the statistical value of the Jarque - Bera test is $\mathrm{JB}(4.408686)<\mathrm{X} 2(9.49)$ or p-value $(0.110323)>\alpha(0.05)$, then the null hypothesis fails to be rejected, which means that the residuals of the research model are normally distributed so that the $\mathrm{t}$ test and the $\mathrm{F}$ test can be done to see the significance of the model. 
Table 6 Multicollinearity Test

\begin{tabular}{|c|c|c|c|}
\hline & Work motivation & Discipline & Job satisfaction \\
\hline Motivation & 1,000000 & 0.329637 & 0.357656 \\
\hline Discipline & 0.329637 & 1,000000 & 0.761292 \\
\hline Job satisfaction & 0.357656 & 0.761292 & 1,000000 \\
\hline
\end{tabular}

Source: Eviews 7, 2019 data processing results

It can be concluded in Table 6 the results of the multicollinearity test on the above variables did not have multicollinearity because they were valued below 0.85 .

Table 7 Heteroscedasticity Test

Heteroskedasticity Test: Glejser

\begin{tabular}{lll}
\hline \hline F-statistic & 2.241902Prob. F (3.96) & 0.0883 \\
Obs * R-squared & 6.547247Prob. Chi-Square (3) & 0.0878 \\
Scaled explained SS & 6.087565Prob. Chi-Square (3) & 0.1074 \\
\hline \hline
\end{tabular}

Source: Eviews 7, 2019 data processing results

Based on table 7 the results of the heteroscedasticity test there is no heteroscedasticity problem. This can be seen from the probability value of chi-square $(0.0878)>\alpha=5 \%(0.05)$.

Table 8 Hypothesis Test

\begin{tabular}{ccccc}
\hline \hline Variable & Coefficient & Std. Error & t-Statistic & Prob. \\
\hline \hline C & 3.482398 & 1,845192 & 1.887282 & 0.0621 \\
Work motivation & 0.576872 & 0.099977 & 5.770061 & 0.0000 \\
Discipline & 0.531239 & 0.146529 & 3.625497 & 0.0005 \\
Job satisfaction & 0.746606 & 0.155546 & 4.799915 & 0.0000 \\
\hline \hline
\end{tabular}

Source: Eviews 7, 2019 data processing results

In Table 8 it is known that the two-sided t distribution at $\mathrm{df}=(\mathrm{NK})$ or $100-4=96$ with $\alpha=5 \%$, the $t$ table value is 1.98498 . It can be concluded that the work motivation variable is t-count (5.770061)>t table (1.98498), which means that there is an influence of work motivation on the performance of employees of PT. Pos Indonesia,Central Jakarta Branch in 2019. And for the t-test results of the discipline variable count equal to3.625497 with a probability of 0.0005 , there is also a disciplining effect on the performance of the employees of PT. Pos Indonesia,Central Jakarta Branch in 2019. Furthermore, for the t-test results of the job satisfaction variable, the t-count is obtained4.799915 with a probability of 0.0000 , which means there is also influence Job satisfaction the Performance of PT. Pos Indonesia,Central Jakarta Branch in 2019.

Table 9 simultaneous Test

\begin{tabular}{ll}
\hline \hline F-statistic & 82.41139 \\
Prob (F-statistic) & 0.000000 \\
\hline \hline
\end{tabular}

Source: Eviews 7, 2019 data processing results 
From the calculation results in table 9 , it can be seen that the test resultsFcountamounting to 82.41139 with a probability of 0.000000 . Based on the F-table with $\mathrm{df}=3.124$ with $\alpha=5 \%$, the F-table value is 2.70 . Then it can be concluded that Fcount (82.41139)> F-table (2.70), which means that there is a joint influence on Work Motivation, Discipline and Job Satisfaction on Employee Performance of PT. Pos Indonesia,Central Jakarta Branch in 2019.

Table 10 Coefficient of Determination (R2)

\begin{tabular}{cc}
\hline \hline R-squared & 0.720308 \\
Adjusted R-squared & 0.711567 \\
\hline \hline
\end{tabular}

Source: Eviews 7, 2019 data processing results

As shown in table 10 calculation results The obtained magnitude of the influence of the independent variable on the dependent variable which can be explained by the model in this equation is equal to 0.720308 or equal to $72.03 \%$. This shows that the variations of the Work Motivation, Discipline and Job Satisfaction variables are able to explain the variations in the rise/fall of Employee Performance (PT. Pos Indonesia Employees) equal to $72.03 \%$ while the remaining $27.97 \%$ is explained by factors other than Work Motivation, Discipline, and Job Satisfaction which were not included in this regression model.

\section{CONCLUSIONS AND SUGGESTIONS Conclusion}

Based on the results of the research and discussion that has been stated in the previous chapter, the conclusions that can be drawn from the results of research regarding Analysis The Influence of Work Motivation, Discipline, Job Satisfaction at PT. Pos Indonesia,Central Jakarta Branch in 2019, are as follows :

1. The results of this study indicate that Work Motivation, Discipline and Job Satisfaction significant effect on employee performance at PT. Pos Indonesia,Central Jakarta Branch in 2019. Therefore, by increasing motivation in the form of rewards for employees, it will also affect to increase discipline and job satisfaction and can have an influence on employee performance.

2. Discipline also has a positive effect on employee performance. This can be seen from the results of the discipline which has a positive and significant effect on employee performance at PT. Pos Indonesia,Central Jakarta Branch. The applied discipline will also affect performance, if the company does not apply discipline concerning timeliness, the existing performance can be disrupted.

3. Job Satisfaction also has a positive effect on Employee Performance. This can be seen from the results of job satisfaction which have a positive and significant impact on employee performance at PT. Pos Indonesia,Central Jakarta Branch. Job satisfaction that is felt in employees will also affect performance, if employees do not feel satisfaction, performance will always be disrupted. However, if employees feel satisfaction, then employees will always love their work.

4. Work motivation has a positive effect on employee performance. This can be seen from the results of work motivation which has a positive and significant effect on employee 
performance at PT. Pos Indonesia,Central Jakarta Branch. The amount of motivation received by employees will also have a positive impact on performance

\section{Suggestion}

1. This research illustrates that Work Motivation, Discipline and Job Satisfaction can affect Employee Performance variables, so that the company or parties working in the service or service sector must pay attention to these variables so that employees can be motivated to continue to provide good service to consumers can be maximized and the performance of employees in the company will be maximized. better.

2. For PT. Pos Indonesia,Central Jakarta Branch, this study illustrates that work motivation, discipline, and job satisfaction influence the performance of its employees. So that PT. Pos Indonesia, Central Jakarta branch is sufficient to provide satisfaction for all parties, both for its employees and the company. Therefore, the management methods that have been implemented and implemented are continuously maintained. However, it would be better if the existing and implemented management methods are added so that in the future the company's goals can be achieved effectively and efficiently.

3. For further researchers, it is hoped that they can research with a larger number of population and respondents so that the resulting data can ensure the magnitude of the influence of work motivation, discipline, and job satisfaction variables on employee performance. And also to carry out deeper studies to develop research variables, so that other findings can be obtained for the development of science.

\section{REFERENCE}

Amiroso, J., \& Mulyanto. (2015). Influence of Discipline, Working Environment, Culture of Organization and Competence on Workers' Performance through Motivation, Job Satisfaction (Study in Regional Development Planning Board of Sukoharjo Regency). European Journal of Business and Management.

Belle, N., \& Cantarelli, P. (2017). Work motivation. In Experiments in Public Management Research: Challenges and Contributions.

Creswell, J. (2013). Qualitative, quantitative, and mixed methods approaches. In Research design.

Hamali, Arif. Yusuf. 2018. Pemahaman Manajemen Sumber Daya Manusia. CAPS (Center for Academic Publishing Service). Jakarta

Hamid, Z., Muzamil, M., \& Shah, S. A. (2019). Strategic human resource management. In Handbook of Research on Positive Organizational Behavior for Improved Workplace Performance.

Hasibuan, S.P. Malayu. Manajemen Dasar, Pengertian, dan Masalah. PT Bumi Aksara. Jakarta

LeSage, J. (2015). Spatial econometrics. In Handbook of Research Methods and Applications in Economic Geography.

Parker, I., \& Parker, I. (2020). Quantitative. In Psychology through Critical AutoEthnography. 
Priansa, Donni. Juni. (2017). Manajemen Kinerja Kepegawaian. CV Pustaka Setia. Bandung, p. 48 .

Rivai, Veithzal. dan Sagala, Ella. Jauvani. (2009)Manajemen Sumber Daya Manusia untuk Perusahaan: Dari Teori ke Praktik. PT Rajagerindo Persada. Jakarta

Sajangbati, A.S. Ivonne. (2013). Motivasi, Disiplin dan Kepuasan pengaruhnya terhadap Kinerja Pegawai PT Pos Indonesia cabang Bitung, in: Jurnal Emba, Vol. 1 (6), p. 669.

Sutrisno, Edy. (2017)a. Manajemen Sumber Daya Manusia. Kencana. Jakarta

Terry, George. R. 2006. Prinsip-Prinsip Manajemen. Penerbit PT Bumi Aksara. Jakarta, p. 9.

Widarjono, Agus. 2013a. Ekonometrika : Pengantar dan Aplikasinya. UPP STIM YKPN. Yogyakarta

https://www.medcom.id/ekonomi/mikro/3NOB3WmK-karyawan-pt-pos-blokade-jalanmedan-merdeka-selatan

https://id.wikipedia.org/wiki/Pos_Indonesia 